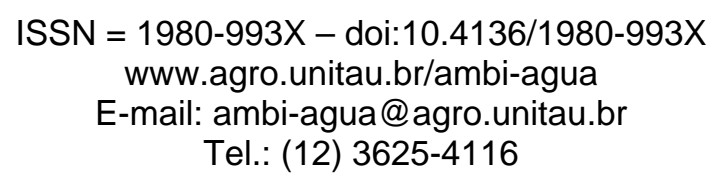

\title{
Accumulation, distribution and toxicological effects induced by chromium on the development of mangrove plant Kandelia candel (L.) Druce
} (doi:10.4136/ambi-agua.70)

\author{
Mohammed Mahabubur Rahman'; Yan Chongling²; Md. Motiur Rahman³; \\ Kazi Shakila Islam ${ }^{4}$ \\ ${ }^{1}$ Education and Research Center for Subtropical Field Science, Kochi University, Nankoku, Japan, 783-8502 \\ E-mail: t_rahman76@yahoo.com \\ ${ }^{2}$ School of Life Sciences, Xiamen University, Xiamen, Fujian-361005, P.R. China \\ E-mail: ycl@xmu.edu.cn \\ ${ }^{3}$ Slivacom Ltd. Edmonton, Alberta, Canada \\ E-mail: Motiur.Rahman08@gmail.com \\ ${ }^{4}$ The School of Oceanography and Environmental Science, Xiamen University, Xiamen, Fujian-361005, China \\ E-mail: shakila_tanee@yahoo.com
}

\begin{abstract}
A study was performed for investigating accumulation, distribution and toxicological effects induced by chromium $(\mathrm{Cr})$ on the development of the mangrove seedling Kandelia candel (L.) Druce. Seedlings treated with increasing concentrations of $\mathrm{CrCl}_{3}$ solution $(0,0.5$, $1,1.5,2,2.5,3 \mathrm{mg} \mathrm{L}^{-1}$, respectively) were grown in a basic nutrient solution for three months. The five month old seedlings were harvested for the experiment. This study showed that $\mathrm{Cr}$ treatment significantly decreased growth of $K$. candel in terms of seedling height, leaf number and total biomass. At the highest $3 \mathrm{mg} \mathrm{L}^{-1} \mathrm{Cr}$ exposure, there was a $34.47 \%$ decrease in final seedling height, $68.95 \%$ decrease in leaf number and a $60.65 \%$ decrease in total biomass. The present study demonstrates that $\mathrm{Cr}$ accumulation ability of $K$. candel seedlings increased with the increase of treatment strength up to certain level. The concentrations of $\mathrm{Cr}$ in root, hypocotyl, stem and leaf ranged from 22.87 to $1.43 \mathrm{mg} \mathrm{kg}^{-1}, 1.30$ to $0.68 \mathrm{mg} \mathrm{kg}^{-1}, 2.42$ to 0.91 $\mathrm{mg} \mathrm{kg}{ }^{-1}$, and 1.74 to $0.74 \mathrm{mg} \mathrm{kg}^{-1}$, respectively. When comparing $\mathrm{Cr}$ concentration in different plant parts with respect to their controls, the results showed that treated plant root bioaccumulated high amounts of $\mathrm{Cr}$. Almost $80 \%$ of $\mathrm{Cr}$ was accumulated mainly in roots. The distribution pattern of $\mathrm{Cr}$ in $\mathrm{K}$. candel was Root $>$ Stem $>$ Leaf $>$ Hypocotyl. Our findings indicated that the high concentration of $\mathrm{Cr}$ supply may interfere with several metabolic processes of seedlings, causing toxicity to plants as exhibited by chlorosis, necrosis, and finally, plant death.
\end{abstract}

Keywords: Chromium; plant growth; metal accumulation; metal distribution pattern; toxic effect; mangrove.

\section{Acumulação, distribuição e efeitos toxicológicos induzidos por cromo no desenvolvimento da planta de mangue Kandelia candel (L.) Druce}

\section{RESUMO}

Este estudo teve o objetivo de investigar a acumulação, a distribuição e os efeitos toxicológicos induzidos por cromo $(\mathrm{Cr})$ no desenvolvimento de mudas da planta de mangue Kandelia candel (L.) Druce. Mudas tratadas com concentrações crescentes de solução de $\mathrm{CrCl} 3\left(0 ; 0,5 ; 1 ; 1.5 ; 2 ; 2,5 ; 3 \mathrm{mg} \mathrm{L}^{-1}\right.$, respectivamente) foram cultivadas em uma solução básica de nutrientes durante três meses. As mudas foram colhidas com cinco meses de idade. Este estudo mostrou que o tratamento com $\mathrm{Cr}$ diminuiu significativamente o crescimento da 
RAHMAN, M. M.; CHONGLING, Y.; RAHMAN, M. M.; ISLAM, K. S. Accumulation, distribution and toxicological effects induced by chromium on the development of mangrove plant Kandelia candel (L.) Druce. Ambi-Agua, Taubaté, v. 4, n. 1, p. 6-19, 2009. (doi:10.4136/ambi-agua.70)

K. candel, em termos da altura da muda, número de folhas e biomassa total. No nível mais alto $\left(3 \mathrm{mg} \mathrm{L}^{-1}\right)$ de exposição ao $\mathrm{Cr}$, houve uma diminuição de $34,47 \%$ na altura final da muda, $68,95 \%$ de diminuição no número de folhas e uma diminuição de $60,65 \%$ na biomassa total. $\mathrm{O}$ presente estudo demonstrou que a habilidade de acumulação $\mathrm{Cr}$ das mudas de K.candel aumentou com o aumento da concentração no tratamento até um certo nível. As concentrações de $\mathrm{Cr}$ na raiz, hipocótilo, caule e folha variaram de 22,87 a $1,43 \mathrm{mg} \mathrm{kg}^{-1}$, de 1,30 a $0,68 \mathrm{mg} \mathrm{kg}^{-1}$, de 2,42 a $0,91 \mathrm{mg} \mathrm{kg}^{-1}$, e de 1,74 a $0,74 \mathrm{mg} \mathrm{kg}^{-1}$, respectivamente. Ao comparar a concentração de $\mathrm{Cr}$ em diferentes partes da planta em relação ao controle, os resultados mostraram que a raiz da planta acumulou grande quantidade de Cr. Foram acumulados quase $80 \%$ de $\mathrm{Cr}$, principalmente nas raízes. O padrão de distribuição do $\mathrm{Cr}$ em K. candel foi raiz $>$ caule $>$ folha $>$ hipocótilo. Os resultados indicaram que a alta concentração de $\mathrm{Cr}$ suprida pode interferir em vários processos metabólicos das mudas, causando toxicidade às plantas manifestada por cloroses, necroses e, por fim, morte de planta.

Palavras-chave: Cromo; crescimento de plantas; acumulação de metais; padrão de distribuiçãode metais; efeito tóxico; mangue.

\section{INTRODUCTION}

Mangroves are trees and shrubs that grow in saline coastal habitats in the tropical and subtropical regions of the world. These ecosystems are highly productive but extremely sensitive and fragile (Hogarth, 1999). Due to industrial development and population expansion, heavy metal pollution in mangrove wetland environment is becoming an increasingly serious problem worldwide. Along the southern coast of China, the severity of impact on coastal habitats has increased dramatically, a wide variety of anthropogenic activities have affected the mangrove ecosystem, as reflected by faecal coliform counts, heavy metal and inorganic nitrogen concentrations exceeding national standards (Chua and Gorre, 2000; Alongi et al., 2005). The sources of metal input are industrial effluents and wastes, urban runoff, sewage treatment plants, boating activities, agricultural fungicide runoff, domestic garbage dumps and mining operations (Tam and Wong, 2000; MacFarlane, 2002; Cox and Preda, 2005; Gonzalez-Mendoza et al., 2007). The heavy metals AS, Cd, Pb, Zn and $\mathrm{Cr}$ are of greatest ecotoxicological concern in Chinese estuaries and are often found in high concentrations in polluted sediments (Zhou and Zhu 2006; Li et al., 2007). Mangrove plants can absorb pollutants from the environment and accumulate them in the bodies. Different species have different abilities to absorb and enrich heavy metals (Lin, 1999). Studies performed with mangrove seedlings exposed to heavy metals have demonstrated a relatively low transport of metals from roots to leaves (Chiu et al., 1995). A number of researchers have found high concentrations of accumulated metals in the tissues of numerous mangrove species in the polluted localities including K. candel, Rhizophora spp. and Avicennia spp. (MacFarlane and Burchett, 2000). Heavy metal contamination is one of the major environmental stresses that affect plant metabolism. Due to its widespread industrial use, $\mathrm{Cr}$ has become a serious pollutant of soil and aquatic bodies (Zayed and Terry, 2003). Cr can be transferred and concentrated into plant tissues from soil, and pose significant damaging effect on the plant. Many studies have appeared in the literature investigating the effects of toxic metals on growth of plants and the distribution of metals (Wong et al., 1988; Moral et al., 1994, and Yim and Tam, 1999), but very little is known about the specific effects and accumulation of heavy metals such as $\mathrm{Cr}$ in mangroves. Thus, the present pot experiment aims to: (1) investigate the effects of $\mathrm{Cr}$ on growth of young $\mathrm{K}$. candel seedlings, (2) determine the distribution and accumulation patterns of $\mathrm{Cr}$ in the various organs of young $K$. candel seedlings, and (3) assess the $\mathrm{Cr}$ toxicity effect on young $K$. candel seedlings. 
RAHMAN, M. M.; CHONGLING, Y.; RAHMAN, M. M.; ISLAM, K. S. Accumulation, distribution and toxicological effects induced by chromium on the development of mangrove plant Kandelia candel (L.) Druce. Ambi-Agua, Taubaté, v. 4, n. 1, p. 6-19, 2009. (doi:10.4136/ambi-agua.70)

\section{MATERIALS AND METHODS}

\subsection{Experimental setup}

For each with 3 replicates in a complete randomized design were set up to examine $\mathrm{Cr}$ ( 7 treatments) accumulation, distribution and their effects on growth of $K$. candel mangrove seedlings.

\subsection{Field collection and germination}

The propagules of $K$. candel were collected from plants grown at the Jiulongjiang mangrove forest stand $\left(24^{\circ} 24^{\prime} \mathrm{N}, 117^{\circ} 23^{\prime} \mathrm{E}\right)$, Xiamen, Fujian, China. The region is subtropical with most of the annual rainfall $(1284 \mathrm{~mm})$ derived from summer typhoons. The average annual temperature range of estuarine waters is from 14.8 to $27.8^{\circ} \mathrm{C}$, with salinities adjacent to the mangroves ranging from 12 to $26 \mathrm{psu}$. After removal of the bracts, only complete, undamaged propagules with testa intact and no emergent hypocotyls or radicles were selected for planting. Propagules chosen for germination were those collected in the most abundant weight class, 18.0-19.55 g fresh weights. Propagules were planted in plastic pots filled with washed sand. Three plastic pots were placed inside a plastic container $(30 \mathrm{~cm}$ long $\times 40 \mathrm{~cm}$ wide $\times 30 \mathrm{~cm}$ high). Four propagules were randomly planted in each plastic pot for germination and growth $(3 \times 4, n=12)$. All the pots were placed in the green house. The propagules were kept in a greenhouse under natural lighting with a temperature of $28 \pm 5^{\circ} \mathrm{C}$. A quantity of 2 liters tap water was irrigated to each pot 2 times each week. The water level of each container was adjusted daily with tap water (free- $\mathrm{NaCl}$ ) to compensate for the amount of water lost by evaporation. Propagules started to germinate within one month. After 3 weeks, the young seedlings were adapted to Hoagland's nutrient solution (Table 1). The solutions were changed every 7 days to prevent depletion of metals, nutrients and oxygen.

Table 1. Basal nutrient solution used for sand culture of Kandelia candel (L.) Druce seedlings.

\begin{tabular}{ccc}
\hline Solution & Chemical composition & Value (g/L) \\
\hline $\mathrm{A}$ & $\mathrm{KNO}_{3}$ & 70.77 \\
& $\mathrm{NH}_{4} \mathrm{H}_{2} \mathrm{PO}_{4}$ & 23.00 \\
$\mathrm{MgSO}_{4} \cdot 7 \mathrm{H}_{2} \mathrm{O}$ & 49.29 \\
$\mathrm{~B}$ & $\mathrm{H}_{3} \mathrm{BO}_{3}$ & 2.86 \\
$\mathrm{CuSO}_{4} \cdot 7 \mathrm{H}_{2} \mathrm{O}$ & 0.08 \\
& $\mathrm{ZnSO}_{4} \cdot \mathrm{H}_{2} \mathrm{O}$ & 0.22 \\
& $\mathrm{MnSO}_{4}$ & 1.55 \\
& $\left(\mathrm{NH}_{4}\right)_{6} \mathrm{MO}_{7} \mathrm{O}_{24} \cdot 4 \mathrm{H}_{2} \mathrm{O}$ & 0.61 \\
& $\mathrm{FeSO}_{4} \cdot 7 \mathrm{H}_{2} \mathrm{O}$ & 5.57 \\
$\mathrm{C}$ & $\mathrm{EDTA}^{\mathrm{N} \mathrm{Na}_{2}}$ & 7.45 \\
& $\mathrm{Ca}\left(\mathrm{NO}_{3}\right)_{2}$ & 118.07 \\
\hline
\end{tabular}

Note: $1 \mathrm{~L}$ Hoagland's solution $=10 \mathrm{ml}$ solution $\mathrm{A}+1 \mathrm{ml}$ solution $\mathrm{B}+1 \mathrm{ml}$ solution $\mathrm{C}+10 \mathrm{ml}$ solution $\mathrm{D}$ with rest of water.

\subsection{Preparation of chromium solution}

$\mathrm{Cr}$ solutions were prepared by dissolving $5.124 \mathrm{~g}$ of chromium chloride salts $\left(\mathrm{CrCl}_{3} .6 \mathrm{H}_{2} \mathrm{O}\right.$, Xilong chemical factory, Guangdong, China.) in $1000 \mathrm{ml}$ of distilled water. From this stock solution, various concentrations $\left(1,1.5,2,2.5\right.$ and $\left.3 \mathrm{mg} \mathrm{L}^{-1}\right)$ of $\mathrm{Cr}$ solution were prepared.

\subsection{Chromium exposure}

Two-months old $K$. candel seedlings were put in individual plastic containers holding $1000 \mathrm{ml}$ of Hoagland's solution prepared with the addition of $\mathrm{Cr}\left(\mathrm{as} \mathrm{CrCl}_{3}\right)$ treatment in seven 
RAHMAN, M. M.; CHONGLING, Y.; RAHMAN, M. M.; ISLAM, K. S. Accumulation, distribution and toxicological effects induced by chromium on the development of mangrove plant Kandelia candel (L.) Druce. Ambi-Agua, Taubaté, v. 4, n. 1, p. 6-19, 2009. (doi:10.4136/ambi-agua.70)

levels: $0,0.5,1,1.5,2,2.5$, and $3 \mathrm{mg} \mathrm{L}^{-1}$. The concentration of the metal ion was maintained by adding tap water up to the mark in the plastic container in order to correct the evaporation loss. Plants were exposed to $\mathrm{Cr}$ for 12 weeks under greenhouse conditions. Control (CK) plants were irrigated with $1000 \mathrm{ml}$ of Hoagland's solution without $\mathrm{CrCl}_{3}$. These exposures were performed in triplicates. After 90 days of cultivation under $\mathrm{Cr}$ stress, the symptoms of heavy metal toxicity appeared in the seedling. On the base of the symptoms of the seedlings after three months, we assessed the effects of Cr toxicity.

\subsection{Analyses of samples}

The propagules were allowed to germinate and grow for five months under glasshouse conditions in sand culture before the experiment started. At the end of 90 days of cultivation of seedlings with heavy metals, the plants were uprooted from the plastic pots, washed thoroughly with tap water and rinsed again in distilled water. The samples were then divided into root, hypocotyl, stem, and leaf portions and the fresh weights (FW) of individual parts were recorded. The samples were oven-dried at $70^{\circ} \mathrm{C}$ to constant weight before taking dry weights (DW). Furthermore, the oven-dried samples were ground with an agate grinder (FW100, China) to pass through a 60 mesh sieve. Heavy metals contents were determined after incinerating the samples in a muffle oven at $550^{\circ} \mathrm{C}$ for $6 \mathrm{~h}$. Samples (about $0.2 \mathrm{~g}$ ) were digested for heavy metal analysis with a mixture of concentrated nitric acid and hydrogen peroxide at $90^{\circ} \mathrm{C}$, adapting the methods of MacFarlane et al. (2003) and Defew et al. (2005). The digested samples were made in to $50 \mathrm{ml}$ volume for root, hypocotyl, stem and leaf tissue and were stored in labeled acid-washed glass vials. Samples were analyzed by inductively coupled plasma-mass spectroscopy ICP-MS (PerkinElmer, America). To ensure precision of ICP-MS results, three replicates of each sample were measured for absorbencies. Metal concentrations were calculated from each replicate absorbance value, which was then used to calculate an average sample metal concentration. All concentrations were expressed in $\mathrm{mg} \mathrm{kg}^{-}$ ${ }^{1}$ on a dry-weight (DW) basis using weights obtained from oven-dried specimens.

\subsection{Statistical analysis}

Two statistical programs (Microsoft Excel 2003 package; SSPS 13.0, Chicago, IL, USA) were used to analyze the data. The descriptive statistics (mean, standard deviation) of the heavy metal concentrations were calculated by using the Microsoft Excel 2003 package. A one way analysis of variance (ANOVA) followed by Duncan's post-hoc test was employed to examine any statistical differences between different treatments in terms of changes in biomass, plant growth parameters, bioaccumulation rate, and distribution of heavy metal concentration. The differences were considered statistically significant when the $p$-value was equal to or less than 0.05 .

\section{RESULTS AND DISCUSSION}

\subsection{Plant growth}

At the end of the three month experiment on five month old seedlings, stem height, and leaf numbers of the Cr-treated K. candel seedlings were found to be significantly less than that of the control (Figure. 1 and 2). As Cr concentration was increased, seedling height at harvest decreased (Table 2). Cr treatments of $1 \mathrm{mg} \mathrm{L}^{-1}$ and above reduced seedling height significantly. The $3 \mathrm{mg} \mathrm{L}^{-1} \mathrm{Cr}$ exposure resulted in a $34.47 \%$ decrease in final height and with the same Cr stress; the leaf number was decreased 68.95\% (Table 2). At the end of three month experimental period the mean stem height and number of leaves ranged from $19.06 \pm$ $0.66 \mathrm{~cm}$ to $12.43 \pm 0.11 \mathrm{~cm}$ and $7.73 \pm 0.20$ to $2.40 \pm 0.60$ and treatment had significant effect on these parameters (Table 2). The high concentration of $\mathrm{Cr}$ inhibits the growth of plants, 
RAHMAN, M. M.; CHONGLING, Y.; RAHMAN, M. M.; ISLAM, K. S. Accumulation, distribution and toxicological effects induced by chromium on the development of mangrove plant Kandelia candel (L.) Druce. Ambi-Agua, Taubaté, v. 4, n. 1, p. 6-19, 2009. (doi:10.4136/ambi-agua.70)

causing chlorosis, and necrosis. It was observed that the older leaves on the lower portion of the plant started to turn yellow and fall off. These findings are supported by other similar studies. For example, it has been reported that high concentration of excessive Cr supply may interfere with several metabolic processes of seedlings, causing toxicity to plants as exhibited by chlorosis, photosynthetic decline and, finally, plant death (Panda and Choudhury, 2005; Shanker et al., 2005). Cr causes reduction of leaf area and biochemical changes responsible for the inhibition of chlorophyll synthesis (Vajpayee et al., 1999), and disorganization of the chloroplast ultrastructure (Panda and Choudhury, 2005).

Table 2. Growth parameter under Cr supply after cultivation of 3 months

\begin{tabular}{ccc}
\hline $\begin{array}{c}\text { Treatment } \\
\left(\mathbf{m g ~ L}^{-\mathbf{1}}\right)\end{array}$ & $\begin{array}{c}\text { Stem height } \\
\mathbf{( c m )}\end{array}$ & $\begin{array}{c}\text { Leaf number } \\
\mathbf{( n )}\end{array}$ \\
\hline $\mathrm{CK}$ & $19.06 \pm 0.66(\mathrm{a})$ & $7.73 \pm 0.20(\mathrm{a})$ \\
0.5 & $18.00 \pm 0.34(\mathrm{~b})$ & $6.40 \pm 0.20(\mathrm{~b})$ \\
1.0 & $17.26 \pm 0.58(\mathrm{c})$ & $5.60 \pm 0.10(\mathrm{c})$ \\
1.5 & $16.80 \pm 0.26(\mathrm{c})$ & $4.70 \pm 0.10(\mathrm{~d})$ \\
2.0 & $14.80 \pm 0.10(\mathrm{~d})$ & $3.80 \pm 0.10(\mathrm{e})$ \\
2.5 & $12.86 \pm 0.05(\mathrm{e})$ & $3.03 \pm 0.15(\mathrm{f})$ \\
3.0 & $12.43 \pm 0.11(\mathrm{e})$ & $2.40 \pm 0.60(\mathrm{~g})$ \\
\hline
\end{tabular}

Note: Mean values in the same column with different letters are significantly different at $\mathrm{p} \leq 0.05$ level. The values were the means and SD of 3 replicates.

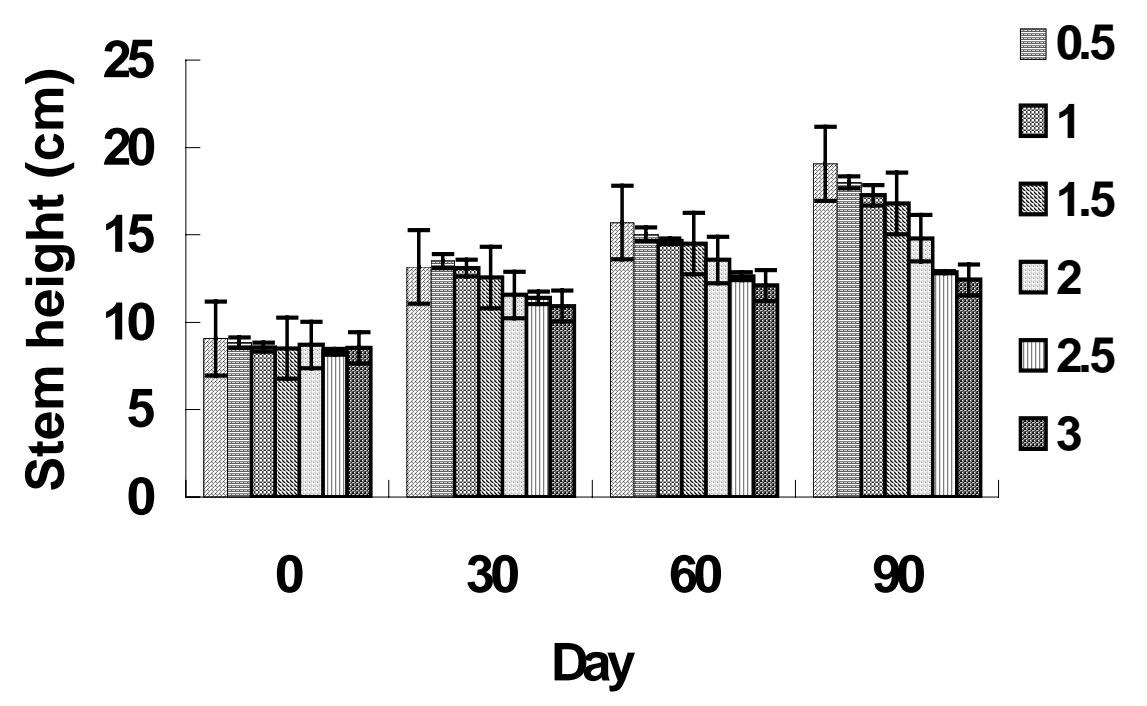

Figure 1. Stem heights of $K$. candel seedlings under different $\mathrm{Cr}$ treatments at different times (mean and standard deviation values of 3 replicates are shown, vertical bars represent $\mathrm{SD}$ ). 


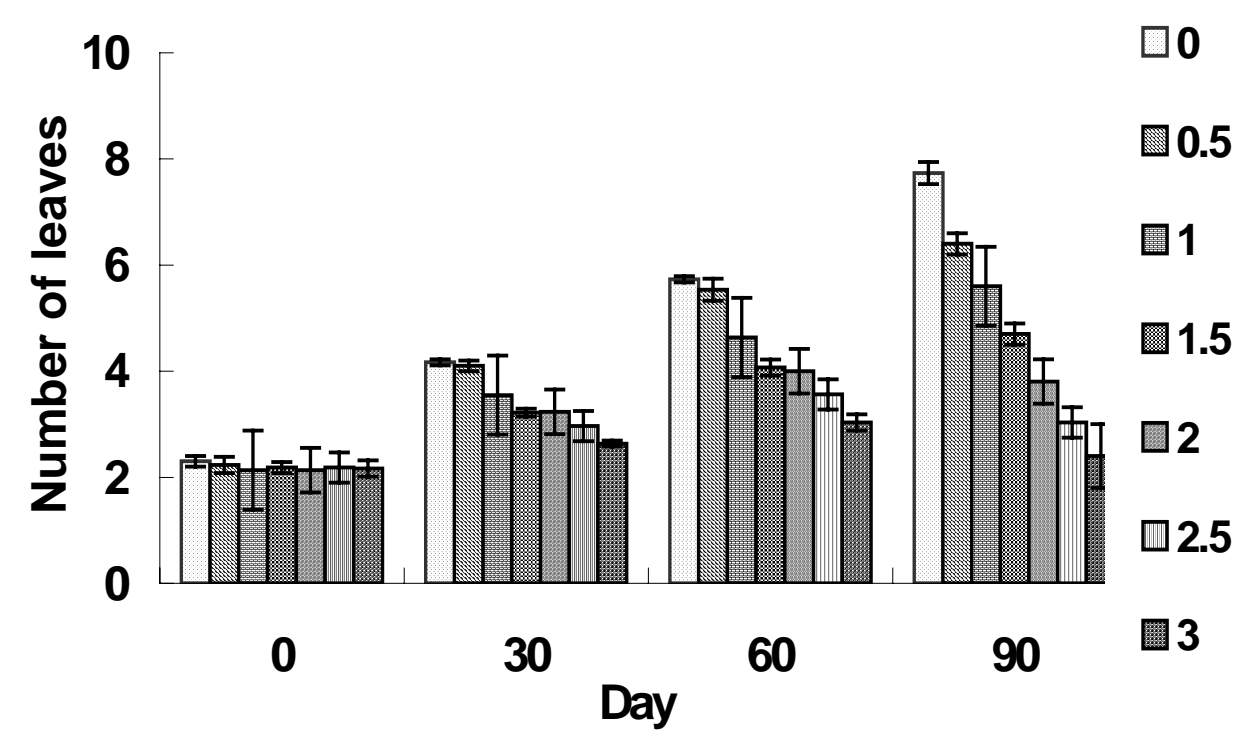

Figure 2. Number of leaves found on $K$. candel under different $\mathrm{Cr}$ treatments at different times (mean and standard deviation of 3 replicates are shown, vertical bars represent $\mathrm{SD})$.

\subsection{Plant biomass}

Increasing the concentrations of $\mathrm{Cr}^{+3}$ ions in the nutrient solution produced a significant growth inhibition of $K$. candel seedlings, measured as dry and fresh weight of root, hypocotyl, stem and leaf. At the highest $\mathrm{Cr}$ concentration $\left(3 \mathrm{mg} \mathrm{L}^{-1}\right)$, total biomass (dry weight DW) was decreased by $60.65 \%$ and the root biomass was decreased by $45.19 \%$ compared to the CK (Table 3). The production of root biomass was reduced due to high $\mathrm{Cr}$ concentration in the sand culture. The heavy metal was found to inhibit root production. The stem biomass decreased significantly with the increase of $\mathrm{Cr}$ concentration in certain levels of the nutrient solutions (Table 3). For example, there was a significant difference between the highest $\mathrm{Cr}$ (3 $\mathrm{mg} \mathrm{L}^{-1}$ ) concentration and the $\mathrm{CK}$ samples. However, from 0.5 to $1.5 \mathrm{mg} \mathrm{L}^{-1}$ concentration there were no significant differences. The reduction in leaf biomass due to the $\mathrm{Cr}$ treatment was more obvious than that of stem biomass (Table 3), suggesting that growth parameters related to leaves were more sensitive than those associated with stems. These findings are consistent with Zhang et al. (2007) who also have found similar results in the Leersia hexandra plants. The differences between $\mathrm{CK}$ and $\mathrm{Cr}$ on growth inhibition were significant in the present study. Cr stress resulted in a significant decrease in plant biomass at the highest concentration in comparison to $\mathrm{CK}$. The decrease in dry weight might be due to accumulation of certain nutrients and $\mathrm{Cr}$ in different parts of $K$. candel grown with excess $\mathrm{Cr}$. The decrease in dry weight might also be due to a reduction in photosynthesis and chlorophyll ' $a$ ' synthesis under excess $\mathrm{Cr}$ conditions (Dube et al., 2003). It has been reported that $\mathrm{Cr}$ readily forms complexes with $-\mathrm{COOH}$ groups, which inhibits the translocation of metal from roots to shoots (Rai et al., 2002). As a consequence, the final dry matter values of roots ranged from $4.52 \pm$ 0.50 to $1.25 \pm 0.57 \mathrm{~g}$ and leaves ranged from $1.73 \pm 0.15$ to $0.4 \pm 0.26 \mathrm{~g}$ when harvested from the Cr-treated plants. Due to its structural similarity with some essential elements, $\mathrm{Cr}$ can affect the mineral nutrition of plants in a complex way (Shanker et al., 2005). Once accumulated and distributed within the plant, it can interact with other essential elements and significantly affect the concentration and distribution of nutrients in the plant, as well as modify morphology and some physiological processes (Barbosa et al., 2007). Formation of complexes of $\mathrm{Cr}$ with organic acids can play an important role in the inhibitory and stimulatory effects of $\mathrm{Cr}$ in the translocation of different mineral nutrients (Panda and Choudhury, 2005). An excess of $\mathrm{Cr}$ interferes in the absorption of $\mathrm{Na}, \mathrm{Fe}, \mathrm{Mn}, \mathrm{Cu}, \mathrm{N}, \mathrm{P}, \mathrm{K}$ 
RAHMAN, M. M.; CHONGLING, Y.; RAHMAN, M. M.; ISLAM, K. S. Accumulation, distribution and toxicological effects induced by chromium on the development of mangrove plant Kandelia candel (L.) Druce. Ambi-Agua, Taubaté, v. 4, n. 1, p. 6-19, 2009. (doi:10.4136/ambi-agua.70)

and $\mathrm{Mg}$ (Barbosa et al., 2007). One of the reasons for the decrease in the absorption of some nutrients in Cr-stressed plants is the inhibition of the plasma membrane $\mathrm{H}^{+}$ATPase activity (Shanker, 2003). Cr strongly inhibits the incorporation of $\mathrm{P}, \mathrm{K}, \mathrm{Ca}, \mathrm{Mg}, \mathrm{Fe}, \mathrm{Mn}, \mathrm{Zn}$ and $\mathrm{Cu}$ in different cellular constituents in Cocos nucifera. The inhibitory effects of $\mathrm{Cr}$ on plant growth are the result of specific interactions between $\mathrm{Cr}$ and $\mathrm{P}, \mathrm{Cr}$ and $\mathrm{Fe}$ or $\mathrm{Cr}$ and $\mathrm{Cu}$ (Barbosa et al., 2007). Such interactions could be associated with the chemical properties of these metals, for example the charge $\left(\mathrm{Cr}^{3+}\right.$ and $\left.\mathrm{Fe}^{3+}\right)$ and the effective ionic radius $(\mathrm{Cr}$ and $\mathrm{Cu})$. Thus, $\mathrm{Cr}$ can reduce the uptake and translocation of mineral nutrients and can induce deficiencies and imbalances of essential nutrients thereby resulting in poor growth and reduced biomass production.

Table 3. Biomass (DW) of different parts of $K$. candel seedlings under $\mathrm{Cr}$ supply after cultivation of 3 months.

\begin{tabular}{clllll}
\hline $\begin{array}{c}\text { Treatment } \\
\mathbf{~ m ~ L ~}^{-1}\end{array}$ & \multicolumn{1}{c}{$\begin{array}{c}\text { Root } \\
\text { DW(g) }\end{array}$} & $\begin{array}{c}\text { Hypocotyl } \\
\text { DW(g) }\end{array}$ & $\begin{array}{c}\text { Stem } \\
\text { DW(g) }\end{array}$ & $\begin{array}{c}\text { Leaf } \\
\text { DW(g) }\end{array}$ & $\begin{array}{c}\text { Total } \\
\text { DW(g/pot) }\end{array}$ \\
\hline CK & $4.52 \pm 0.50(\mathrm{a})$ & $11.90 \pm 0.89(\mathrm{a})$ & $1.4 \pm 0.16(\mathrm{a})$ & $1.73 \pm 0.15(\mathrm{a})$ & $19.56 \pm 1.70$ \\
0.5 & $3.39 \pm 0.43(\mathrm{a})$ & $11.13 \pm 0.62(\mathrm{ab})$ & $1.11 \pm 0.16(\mathrm{~b})$ & $1.4 \pm 0.44(\mathrm{ab})$ & $17.04 \pm 1.67$ \\
1.0 & $2.79 \pm 0.42(\mathrm{bc})$ & $10.06 \pm 0.84(\mathrm{bc})$ & $0.96 \pm 0.22(\mathrm{bc})$ & $1.16 \pm 0.71(\mathrm{bc})$ & $14.99 \pm 2.0$ \\
1.5 & $2.51 \pm 1.42(\mathrm{bc})$ & $9.4 \pm 1.26(\mathrm{~cd})$ & $0.78 \pm 0.54(\mathrm{bcd})$ & $1.00 \pm 0.40(\mathrm{bcd})$ & $13.7 \pm 3.63$ \\
2.0 & $1.91 \pm 0.98(\mathrm{c})$ & $8.56 \pm 0.20(\mathrm{~d})$ & $0.61 \pm 0.33(\mathrm{~cd})$ & $0.6 \pm 0.36(\mathrm{~cd})$ & $11.69 \pm 1.87$ \\
2.5 & $1.50 \pm 0.66(\mathrm{~cd})$ & $7.12 \pm 0.42(\mathrm{e})$ & $0.46 \pm 0.19(\mathrm{de})$ & $0.53 \pm 0.10(\mathrm{de})$ & $9.62 \pm 1.38$ \\
3.0 & $1.25 \pm 0.57(\mathrm{~d})$ & $5.76 \pm 0.42(\mathrm{f})$ & $0.36 \pm 0.16(\mathrm{e})$ & $0.4 \pm 0.26(\mathrm{e})$ & $7.78 \pm 1.43$ \\
\hline
\end{tabular}

Note: Mean values in the same column with different letters are significantly different at $\mathrm{p} \leq 0.05$ level. The values were the means and SD of 3 replicates.

\subsection{Accumulation of $\mathrm{Cr}$ in different parts of $\mathrm{K}$. candel seedlings}

Under the different $\mathrm{Cr}$ treatments in sand culture condition, the $\mathrm{Cr}$ concentrations in roots, hypocotyls, stems, and leaves of $K$. candel seedlings are shown in Figure 3 . The $\mathrm{Cr}$ concentration in roots ranged from 22.87 to $1.43 \mathrm{mg} \mathrm{kg}^{-1}$. The maximum $\mathrm{Cr}$ concentration in the dry root matter was $22.87 \mathrm{mg} \mathrm{kg}^{-1}$, which was significantly higher than the $\mathrm{CK}$. The concentration in hypocotyls ranged from 1.22 to $0.68 \mathrm{mg} \mathrm{kg}^{-1}$. The $\mathrm{Cr}$ concentration in stems ranged from 2.42 to $1.30 \mathrm{mg} \mathrm{kg}^{-1}$. The $\mathrm{Cr}$ concentration in the leaves ranged from 1.98 t0 0.98 $\mathrm{mg} \mathrm{kg}^{-1}$. Ninety days after $\mathrm{Cr}$ treatment, lower $\mathrm{Cr}$ concentration was detected in leaves. On the other hand, when comparing the heavy metal concentration in different tissues, we observed that the $\mathrm{Cr}$ concentrations were $22.87 \mathrm{mg} \mathrm{kg}^{-1}$ in the roots (Figure 3A), $1.30 \mathrm{mg} \mathrm{kg}^{-}$ ${ }^{1}$ in the hypocotyls ( Figure 3B), $2.42 \mathrm{mg} \mathrm{kg}^{-1}$ in the stems (Figure 3C) and $1.74 \mathrm{mg} \mathrm{kg}^{-1}$ in the leaves (Figure 3D). When comparing Cr concentrations in different plant parts with respect to their CK, the results showed that treated plant root bioaccumulated high amounts of this metal. The reason of the high accumulation in roots of the plants could be because $\mathrm{Cr}$ is immobilized in the vacuoles of the root cells, thus rendering it less toxic, which may be a natural toxicity response of the plant (Shanker et al., 2004). The results showed that after $22.87 \mathrm{mg} \mathrm{kg}^{-1} \mathrm{Cr}$ concentration, the seedling could not accumulate more $\mathrm{Cr}$ from the restricted environment. Under the treatments of 2.5 and $3 \mathrm{mg} \mathrm{L}^{-1}$, the seedlings showed significant amount of decrease in $\mathrm{Cr}$ accumulation. It may be the cause for seedlings cell malfunction, cell damaging, and the depletion in chlorophyll. It has been reported that high concentration of excessive $\mathrm{Cr}$ supply may interfere with several metabolic processes of seedlings, causing toxicity to plants (Panda and Choudhury, 2005; Shanker et al., 2005). 
RAHMAN, M. M.; CHONGLING, Y.; RAHMAN, M. M.; ISLAM, K. S. Accumulation, distribution and toxicological effects induced by chromium on the development of mangrove plant Kandelia candel (L.) Druce. Ambi-Agua, Taubaté, v. 4, n. 1, p. 6-19, 2009. (doi:10.4136/ambi-agua.70)

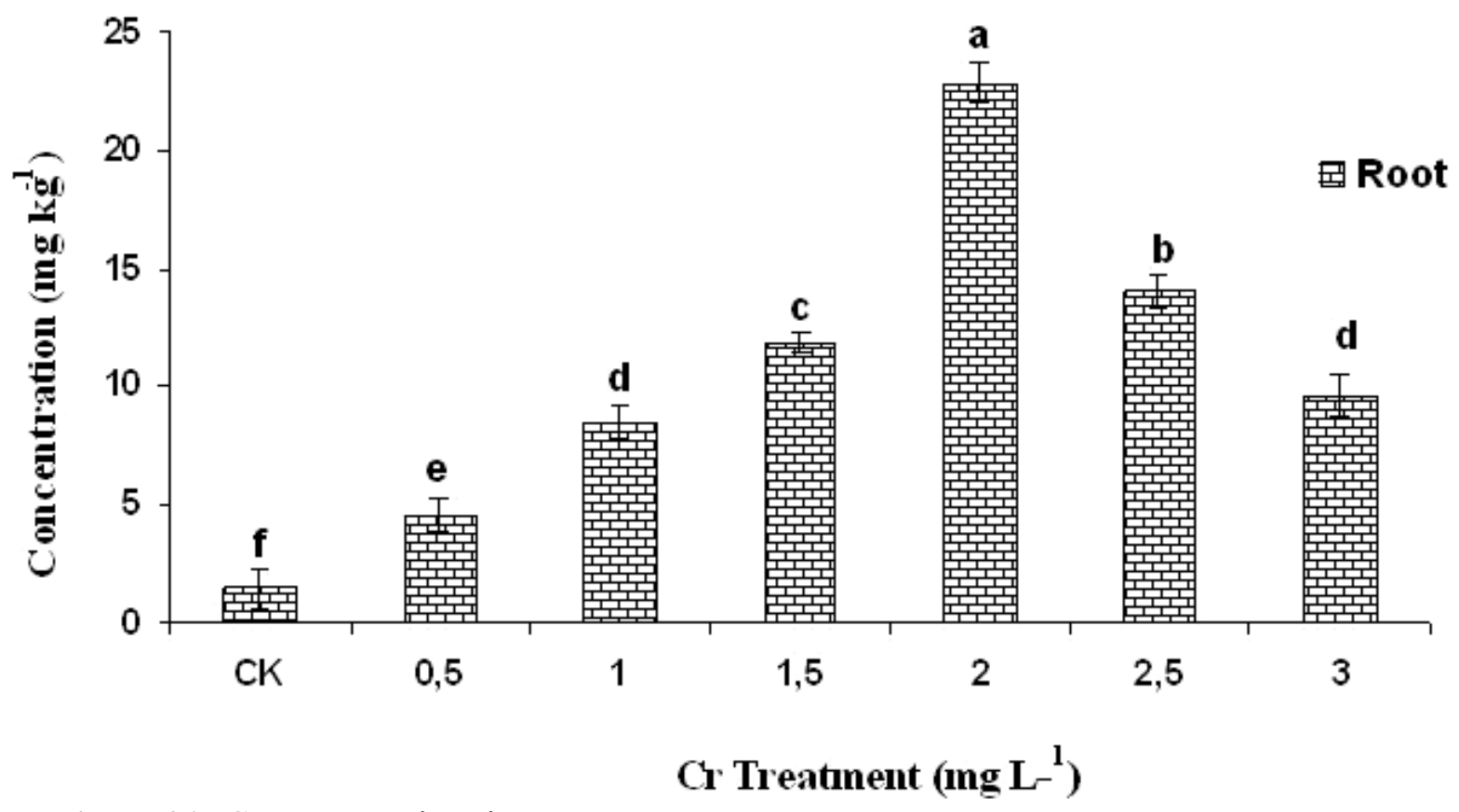

Figure 3A. Cr concentrations in roots.

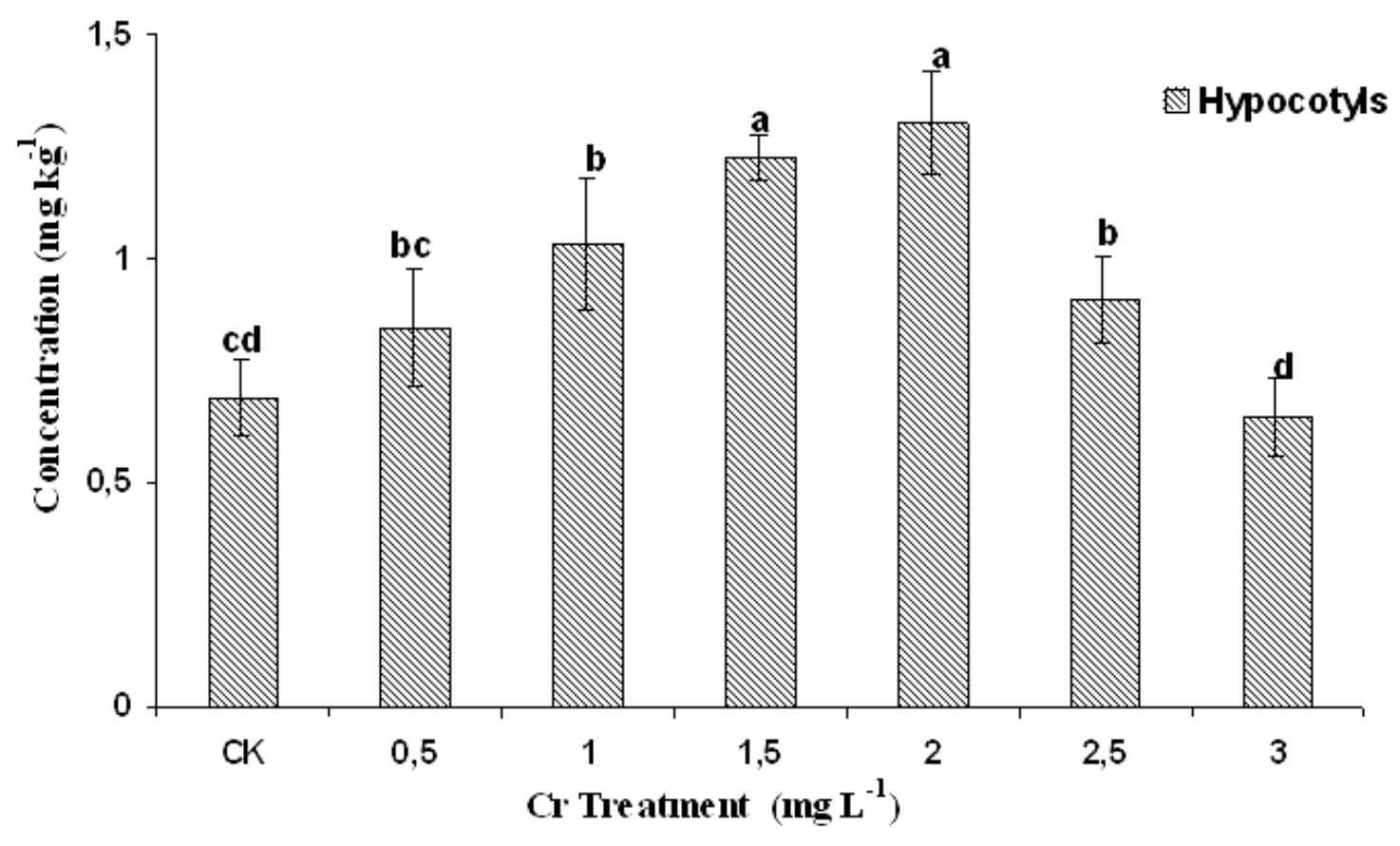

Figure 3B. Cr concentrations in hypocotyls. 


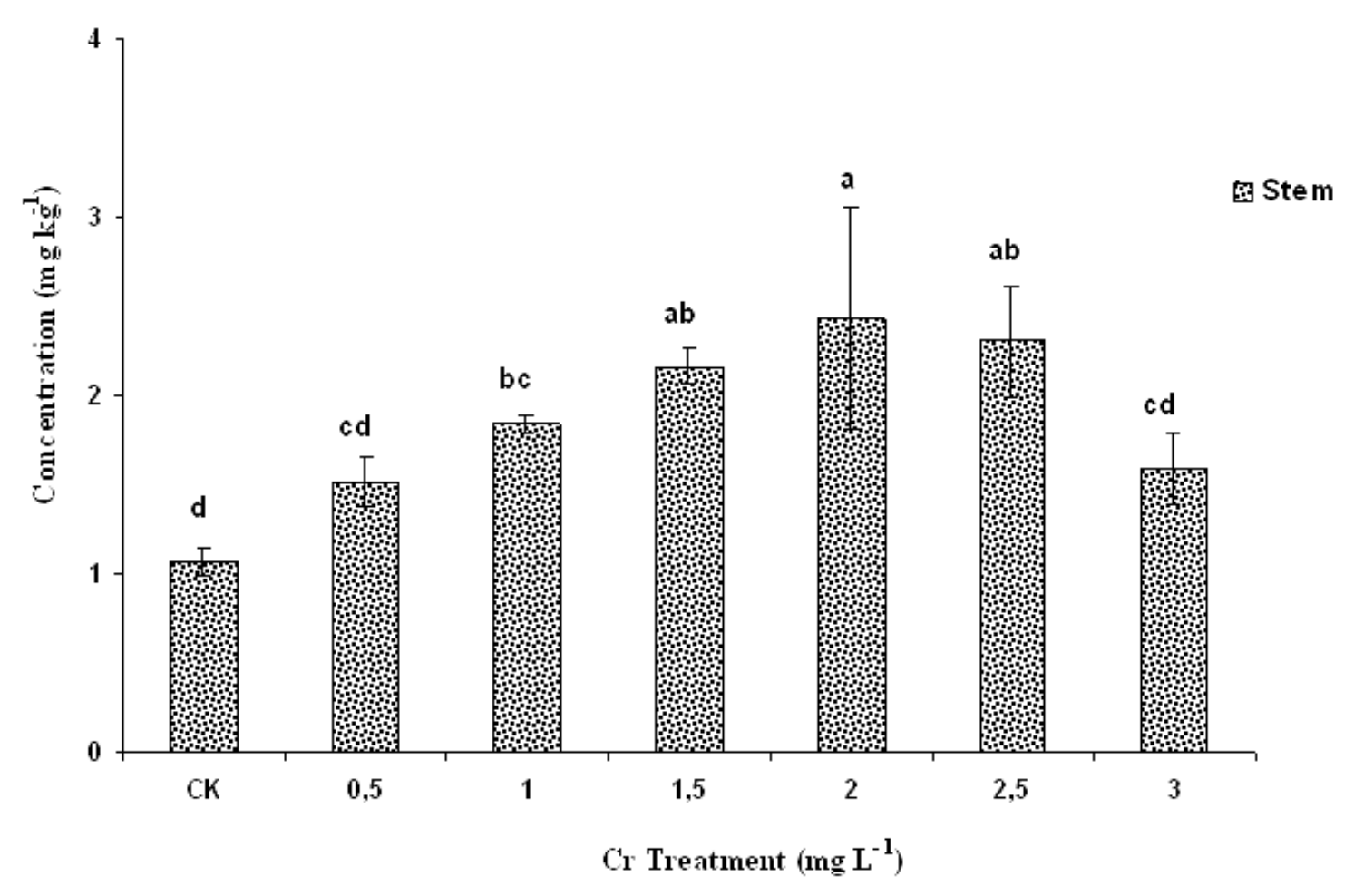

Figure 3C. Cr concentrations in stems.

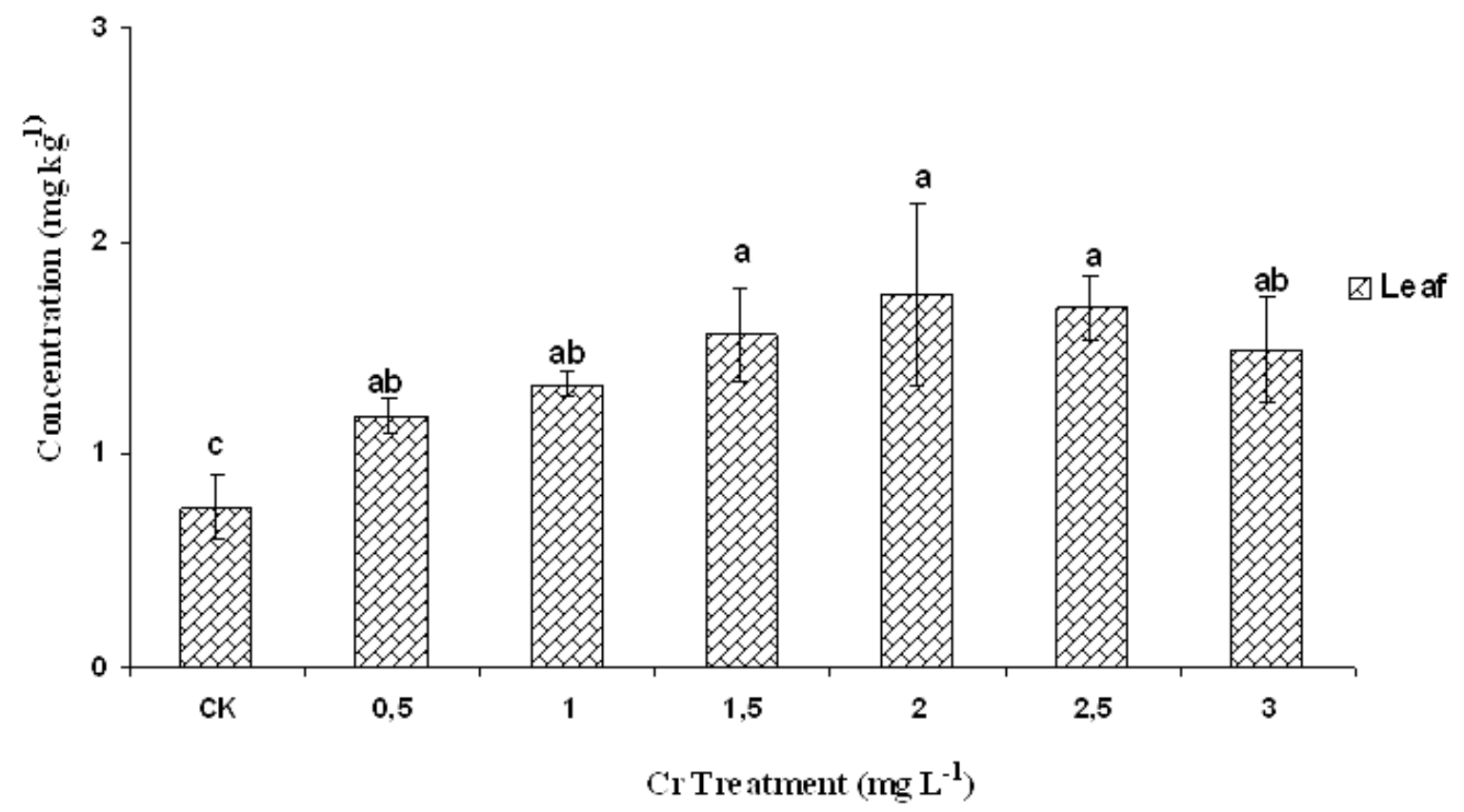

Figure 3D. Cr concentrations in leaves.

Figure 3 (A, B, C, D). Cr concentrations in different parts of $K$. candel seedlings under different $\mathrm{Cr}$ stresses (Mean \pm S.D). Different letters on the vertical bars indicate statistical significance $(p \leq 0.05)$ of difference between the means according to Duncan's test.

\subsection{Distribution pattern of $\mathrm{Cr}$ in different parts of $K$. candel seedlings}

Increased levels of heavy metals such as $\mathrm{Cr}$ in $\mathrm{K}$. candel seedlings generally resulted in higher heavy metal concentrations in mangrove plants, but the degree of increase in different plant parts were varied (Figure 4). The heavy metal concentrations in roots were significantly higher than those found in the other plant parts. At low to medium heavy metal inputs (the 0 
and $2 \mathrm{mg} \mathrm{L}^{-1}$ treatments), most added heavy metals were accumulated in roots, with little transportation to the leaf and stem portions. The roots have been known as an absorptive sponge to heavy metals in soil and water. Metals absorbed or adsorbed by roots are often bound with the cell wall material or other macromolecules to prevent them from translocation to the sensitive plant parts (Chen et al., 1995). When the Cr concentration increased, the defensive mechanism of roots (as a barrier) might have been exhausted and more metals were found in either leaves or stems. In addition, it is known that $\mathrm{Cr}$ is passively taken up and retained by cation exchange sites of the cell wall (Shanker et al., 2005). Therefore, such a non-specific absorption to cell walls could be another way to immobilize the metal at the root level. The distribution pattern of $\mathrm{Cr}$ in $\mathrm{K}$. candel was Root $>$ Stem $>$ Leaf $>$ Hypocotyl. From our investigation we found that the root accumulated the greatest amount of heavy metal at almost $80 \%$ (Figure 4).

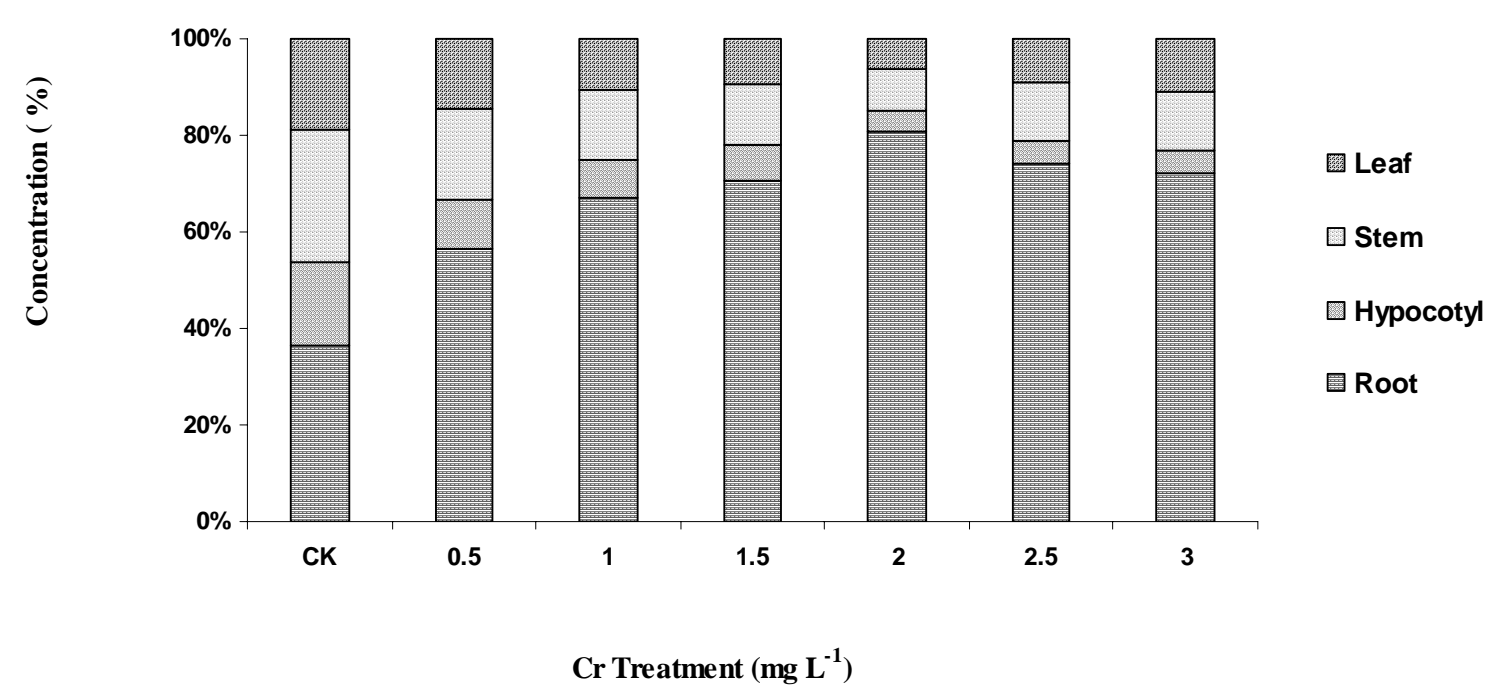

Figure 4. Distribution pattern of $\mathrm{Cr}$ in different parts of $K$. candel seedlings.

\subsection{Bioaccumulation factor of $\mathrm{Cr}$ in $\mathrm{K}$. candel}

The $\mathrm{Cr}$ uptake in different parts of the plants was calculated using the bioaccumulation factor $(B A F)$. The $B A F$ provides an index of the ability of the plant to accumulate a particular metal with respect to its concentration in the medium (Tam and Wong, 1997; Zayed et al., 1998; Ghosh and Singh, 2005), which is calculated as follows:

$$
B A F=\frac{\text { Trace element conc. in plant tissue }\left(\mathrm{mg} \mathrm{kg}^{-1}\right) \text { at harvest }}{\text { Conc. of the element is the external nutrient solution added }\left(\mathrm{mg} \mathrm{kg}^{-1}\right)} \times 100
$$

The bioaccumulation coefficient of roots, hypocotyls, stems, and leaves ranged from 1143.75 to $143.60,169.56$ to $21.64,303.10$ to 52.99 and 251.46 to 60.75 , respectively. When the plants were exposed to $2 \mathrm{mg} \mathrm{L}^{-1} \mathrm{Cr}$ treatment, the bioaccumulation coefficient reached a maximum in roots (1143.75) and significantly higher than those of other treatments (Table 4). The $\mathrm{Cr}$ bioaccumulation rate in roots ranged from 1143.75 to 143.60 . The maximum $\mathrm{Cr}$ bioaccumulation rate in the root was 1143.75 , which was significantly higher than the CK.

\subsection{Assessment of effects of $\mathrm{Cr}$ toxicity on $\mathrm{K}$. candel seedlings}

In three months cultivation under $\mathrm{Cr}$ stress, the symptoms of heavy metal toxicity appeared in the seedlings. The initial symptom of $\mathrm{Cr}$ toxicity appeared to cause chlorosis in $K$. candel seedlings. Chlorosis appeared in the upper leaves of seedlings as an effect of $\mathrm{Cr}$, 
RAHMAN, M. M.; CHONGLING, Y.; RAHMAN, M. M.; ISLAM, K. S. Accumulation, distribution and toxicological effects induced by chromium on the development of mangrove plant Kandelia candel (L.) Druce. Ambi-Agua, Taubaté, v. 4, n. 1, p. 6-19, 2009. (doi:10.4136/ambi-agua.70)

Table 4. Bioaccumulation factors for $\mathrm{Cr}$ in $\mathrm{K}$. candel (an average of three replicates).

\begin{tabular}{crcrr}
\hline Treatment & Root & Hypocotyls & Stem & Leaf \\
\hline CK & 143.60 & 68.90 & 106.91 & 74.9 \\
0.5 & 911.39 & 169.56 & 303.10 & 235.4 \\
1.0 & 850.37 & 103.27 & 183.54 & 132.9 \\
1.5 & 791.59 & 81.64 & 144.28 & 104.0 \\
2.0 & 1143.75 & 65.21 & 121.35 & 87.3 \\
2.5 & 561.118 & 36.36 & 92.16 & 67.5 \\
3.0 & 321.13 & 21.64 & 52.99 & 49.7 \\
\hline
\end{tabular}

probably due to the retardation of Fe and $\mathrm{Zn}$ translocation. The primary toxic effect seemed to be membrane damage due to the high oxidative potential of Cr. Severe necrosis was observed in the lower leaves of $K$. candel seedling with increased $\mathrm{Cr}$ concentrations. The statistical analysis showed that the toxic effects on the seedling stem height, leaf number and biomass were significantly $(p \leq 0.05)$ different with increasing $\mathrm{Cr}$ concentrations at $3 \mathrm{mg} \mathrm{L}^{-1}$. Metal sensitivity and toxicity is influenced by the concentration range of the toxicant the length of the exposure period, and the life-stage or biological process (germination, seedling survival, vegetative growth) examined and hence are important considerations in toxicity assessment (Ernst and Nelissen, 2000). Moreover, very little information exists on the relative sensitivities of semi-aquatic angiosperms to heavy metals (Mohan and Hosetti, 1999), or the combined effects of metals to plants, as exposure to mixtures are more reflective of environmental situations and may alter biological responses in quantitative ways relative to that of single toxicants (MacFarlane and Burchett, 2002). Cr treatment had toxicity effect on the roots and leaves suggesting that metal toxicity induces stress, at least for the duration of exposure considered in the present study. Table 5 shows the visible toxicity symptoms on $K$. candel seedlings under different $\mathrm{Cr}$ stresses. Cr stress can induce metabolic modifications in plants, such as alterations in photosynthesis (Barbosa et al., 2007), degradation of photosynthetic pigments and induction of oxidative stress (Panda and Choudhury, 2005).

Table 5. Visible symptoms on seedlings of K. candel with increasing Cr concentrations.

\begin{tabular}{c|l|c}
\hline $\begin{array}{c}\text { Cr treatments } \\
\left(\mathbf{m g ~ L}^{-1}\right)\end{array}$ & \multicolumn{1}{|c}{ Visible symptoms } & \multicolumn{1}{|c}{$\begin{array}{c}\text { Stem growth } \\
\text { Reduction (\%) }\end{array}$} \\
\hline CK & No symptoms & 0.00 \\
0.5 & No obvious symptoms & 5.59 \\
1 & Chlorosis & 9.44 \\
1.5 & Chlorosis, reddish-brown discoloration of the leaf & 11.88 \\
2 & blades & 22.36 \\
2.5 & Chlorosis (+), necrosis & 32.51 \\
3 & $\begin{array}{l}\text { Chlorosis (++), necrosis (+), root worsened with less } \\
\text { root hair }\end{array}$ & 34.79 \\
& $\begin{array}{l}\text { Chlorosis (+++), necrosis (++), senescence, root } \\
\text { becomes shorter and thicker, root hairs sparser and } \\
\text { color is black and brown, and stem deep brown in } \\
\text { color, plant stared to die. }\end{array}$ & \\
\hline
\end{tabular}

Note: Relative symptom intensity is given in brackets. Percent of growth reduction is given to the $0 \mathrm{mg} \mathrm{L^{-1 } \mathrm { Cr }}$ treatment. 


\section{CONCLUSIONS}

The present study clearly shows that $\mathrm{Cr}$ has significant effects on the $K$. candel seedlings growth parameters. This heavy metal decreased the $K$. candel seedlings stem height, leaf number and total biomass with increased concentrations. At the end of the three months experiment, stem height, leaf number and biomass of the Cr-treated $K$. candel seedlings were significantly less than those of the control. At the highest $\mathrm{Cr}\left(3 \mathrm{mg} \mathrm{L}^{-1}\right)$ exposure, a $34.47 \%$ decrease in final seedling height, $68.95 \%$ decrease in leaf number and $60.65 \%$ decrease in total biomass were noted. The $\mathrm{Cr}$ absorption abilities for different parts of the plant also varied. Roots can accumulate the highest percentage of heavy metal. The heavy metal concentrations in various plant parts increased with the increase concentration of heavy metal in the treatment. K. candel can be affected by very low concentrations of Cr. With a continuous supply of a Cr solution at a concentration of $3 \mathrm{mg} \mathrm{L}^{-1}$, the poisoned root system turned to black-brown and 90 days later the seedlings began to die.

\section{REFERENCES}

ALONGI, D. M.; PFITZNER, J.; TROTT, L. A.; TIRENDI, F.; DIXON, P.; KLUMPP, D.W. Rapid sediment accumulation and microbial mineralization in forests of the mangrove Kandelia candel in the Jiulongjiang Estuary, China. Estuarine, Coastal and Shelf Science, v. 63, p. 605-618, 2005.

BARBOSA, R. M. T.; ALMEIDA, A-A F.; MIELKE, M. S.; LOGUERCIO, L. L.; MANGABEIRA, P. A. O.; GOMES, F. P. A physiological analysis of Genipa americana L.: A potential phytoremediator tree for chromium polluted watersheds. Environmental and Experimental Botany, v. 61, p. 264-271, 2007.

CHEN, G. Z.; MIAO, S. Y.; TAM, N. F. Y.; WONG, Y.S.; LI, S. H.; LAN, C. Y. Effect of synthetic wastewater on young Kandelia candel plants growing under greenhouse conditions. Hydrobiologia, v. 295, p. 263-274, 1995.

CHIU, C. Y.; HSIU, F. S.; CHEN, S. S.; CHOU, C. H. Reduced toxicity of $\mathrm{Cu}$ and Zn to mangrove seedlings in saline environments. Botany Bulletin of Academia Sinica, v. 36, p. 19-24, 1995.

CHUA, T. E.; GORRE, I. R. Xiamen region, China. In: SHEPPARD, C. (Ed.), 2000. Seas at the millennium: an environmental evaluation. Amsterdam: Elsevier Science 2000. p. 513-533.

COX, M.; PREDA, M. Trace metal distribution within marine and estuarine sediments of western moreton bay, Queensland, Australia: relation to land use and setting. Geographical Research, v. 43, p. 173-193, 2005.

DEFEW, L. H.; MAIR, J. M.; GUZMAN, H. M. An assessment of metal contamination in mangrove sediments and leaves from Punta Mala Bay, Pacific Panama. Marine Pollution Bulletin, v. 50, p. 547-552, 2005.

DUBE, B. K.; TEWARI, K.; CHATTERJEE, J.; CHATTERJEE, C. Excess chromium alters uptake and translocation of certain nutrients in citrullus. Chemosphere, v. 53, p. 11471153, 2003. 
ERNST, W. H. O.; NELISSEN, H. J. M. Life-cycle phases of a zinc- and cadmium-resistant ecotype of Silene vulgaris in risk assessment of polymetallic mine soils. Environmental Pollution, v. 97, p. 229-338, 2000.

GHOSH, M.; SINGH, S. P. A comparative study of cadmium phytoextraction by accumulator and weed species. Environmental Pollution, v. 133, p. 365-371, 2005.

GONZALEZ-MENDOZA, D.; GOLD-BOUCHOT, G.; ESCOBEDO-GRACI, R. M. et al. Coordinated responses of phytochelatin synthase and metallothionein genes in black mangrove, Avicennia germinans, exposed to cadmium and copper. Aquatic Toxicology, v. 83, p. 306-314, 2007.

HOGARTH, P. J. The biology of mangroves. Oxford: Oxford University Press, 1999. p. 15$25 \mathrm{p}$.

LI, G.; CAO, Z.; LAN, D. et al. Spatial variations in grain size distribution and selected metal contents in the Xiamen Bay, China. Environmental Geology, v. 52, p. 15591567, 2007.

LIN, P. Mangrove ecosystem in China. Beijing: Science Press, 1999. 232p.

MACFARLANE, G. R.; BURCHETT, M. D. Cellular distribution of copper, lead and zinc in the grey mangrove, Avicennia marina (Forsk.) Vierh. Aquatic Botany, v. 68, p. 45-59, 2000 .

MACFARLANE, G. R. Leaf biochemical parameters in Avicennia marina (Forsk.) Vierh. as potential biomarkers of heavy metal stress in estuarine ecosystems. Marine Pollution Bulletin, v. 44, p. 244-256, 2002.

MACFARLANE, G. R.; BURCHETT, M. D. Toxicity, growth and accumulation relationships of copper, lead and zinc in the grey mangrove Avicennia marina (Forsk.) Vierh. Marine Environmental Research, v. 54, p. 65-84, 2002.

MACFARLANE, G. R.; PULKOWNIKB, A.; BURCHETT, M. D. Accumulation and distribution of heavy metals in the grey mangrove, Avicennia marina (Forks.) Vierh.: biological indication potential. Environmental Pollution, v. 123, p. 129-151, 2003.

MOHAN, B. S.; HOSETTI, B. B. Aquatic plants for toxicity assessment. Environmental Research, v. 81, p. 259-274, 1999.

MORAL, R.; GOMEZ, I.; NAVARRO, P. J.; MATAIX, J.; Effects of cadmium on nutrient distribution, yield, and growth of tomato grown in soilless culture Journal of Plant Nutrition, v. 17, p. 953-962, 1994.

PANDA, S. K.; CHOUDHAURY, S. Chromium stress in plants. Brazilian Journal of Plant Physiology, v. 17, p. 95-102, 2005.

RAI, R. D.; TRIPATHI, P.; VAJPAYEE, V. N.; JHA, V.; ALI, M. B. Bioaccumula-tion of toxic metals $(\mathrm{Cr}, \mathrm{Cd}, \mathrm{Pb}$, and $\mathrm{Cu}$ ) by seeds of Euryale ferox Salisb. (Makhana). Chemosphere, v. 46, p. 267-272, 2002.

SHANKER, A. K.; CERVANTES, C.; LOZA, T. H.; AVUDAINAYAGAM. Chromium toxicity in plants. Environment International, v. 31, p. 739- 753, 2005. 
SHANKER, A. K.; DJANAGUIRAMAN, M.; SUDHAGAR, R.; CHANDRASHEK- AR, C. N.; PATHMANABHAN, G. Differential antioxidative response of ascorbate glutathione pathway enzymes and metabolites to chromium speciation stress in green gram (Vigna radiate (L) R. Wilczek, cv CO4) roots . Plant Science, v. 166, p. 10351043, 2004.

SHANKER, A. K. Physiological, biochemical and molecular aspects of chromium toxicity and tolerance in selected crops and tree species. 2003, Dissertation (Ph.D in plant physiology) - Tamil Nadu Agricultural University, Coimbatore, 2003.

TAM, N. F. Y.; WONG, W. S. Spatial variation of heavy metals in surface sediments of Hong Kong mangrove swamps. Environmental Pollution, v. 110, p. 195-205, 2000.

TAM, N. F. Y.; WONG. Y. Accumulation and distribution of heavy metals in a simulated mangrove system treated with sewage. Hydrobiologia, v. 352, p. 67-75, 1997.

VAJPAYEE, V. N.; SHARMA, S. C.; RAI, U. N.; YUNUS, M. Bioaccumulation of chromium and toxicity to photosynthetic pigment, nitrate reductase and protein content of Nelumbo nucifera Gaetrn. Chemosphere, v. 39, p. 2159-2169, 1999.

WONG, Y. S.; LAM, H. M.; DHILLON, E. Physiological effects and uptakes of cadmium in Pisum sativum. Environmental International, v. 14, p. 535-543, 1988.

YIM, M. W.; TAM, N. F. Y. Effects of wastewater-borne heavy metals on mangrove plants and soil microbial activities. Marine Pollution Bulletin, v. 39, p. 179-186, 1999.

ZAYED, A.; LYTLE, M. C.; JIN-HONG, Q.; TERRY, N. Chromium accumulation, translocation and chemical speciation in vegetable crop. Planta, v. 206, p. 293-299, 1998.

ZAYED, A.; TERRY, N. Chromium in the environment: factors affecting biological Remediation. Plant Soil, v. 249, p. 139-156, 2003.

ZHANG, X. H.; JIE, L.; HAI, T. H.; JUN, C.; YI, N. Z.; DUN, Q. W. Chromium accumulation by the hyperaccumulator plant Leersia hexandra Swartz. Chemosphere, v. 60 , p. 1138-1143, 2007.

ZHOU, M.; ZHU, M. Progress of the project, ecology and oceanography of harmful algal blooms in China. Advanced Earth Science, v. 21, p. 673-679, 2006. 